\title{
Trigger finger genetics and its tendon pathology
}

Anna-Carin Lundin

From 10th Congress of the Asia-Pacific Federation of Societies of Surgery fo the Hand and the 6th Congress of Asia-Pacific Federation of Societies of Hand Therapists

Kuala Lumpur, Malaysia. 2-4 October 2014

The pathogenesis of trigger finger has generally been ascribed to primary changes in the first annular ligament. In contrast, we recently found histological changes in the tendons, similar to the findings in Achilles tendinosis. When we looked further for more similarities we found differences in gene expression in the trigger finger tendons in comparison to normal tendons, in a pattern similar to what is published for Achilles tendinosis. We also found SNP (Single Nucleotide Polymorphism) pattern difference with similarities with what is published for Achilles tendinosis.

Published: 19 May 2015

Submit your next manuscript to BioMed Central and take full advantage of:

- Convenient online submission

- Thorough peer review

- No space constraints or color figure charges

- Immediate publication on acceptance

- Inclusion in PubMed, CAS, Scopus and Google Scholar

- Research which is freely available for redistribution

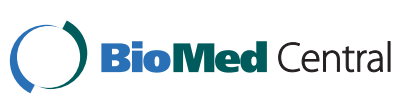

(c) 2015 Lundin; licensee BioMed Central Ltd. This is an Open Access article distributed under the terms of the Creative Commons Attribution License (http://creativecommons.org/licenses/by/4.0), which permits unrestricted use, distribution, and reproduction in any medium, provided the original work is properly cited. The Creative Commons Public Domain Dedication waiver (http:// creativecommons.org/publicdomain/zero/1.0/) applies to the data made available in this article, unless otherwise stated. 